\title{
The Relation Between Knowledge and Attitude towards Behavior of Personal Protective Equipment Usage in Nurses
}

\author{
Hubungan Antara Pengetahuan Dan Sikap Terhadap Perilaku Penggunaan Alat \\ Pelindung Diri Pada Perawat
}

\author{
Gading Diah Zahara Putri, Y. Denny A. Wahyudiono \\ Department of Occupational Safety and Health, Faculty of Public Health Universitas Airlangga \\ Campus C Mulyorejo, Surabaya, East Java 60115, Indonesia
}

\begin{abstract}
Introduction: Nurses are health workers who have the highest intensity of interactions with patients, so they have high risk of exposure to hazards in a workplace. Work accidents and nosocomial infections are hazards in hospitals that can threaten the safety and health of nurses. The proper use of Personal Protective Equipment is, therefore, mandatory to be implemented as an effort to prevent and minimize the risk of exposure or infection. This research was conducted to identify nurses' behavior of Personal Protective Equipment (PPE) usage as well as to identify the relation between the level of knowledge and attitude as an internal factor of an individual in nurses' behavior of PPE usage. Method: The research method used was observational with a cross-sectional study research design. The sample used in this research was determined by the total number of population, which was 12 nurses of pulmonary inpatient rooms at RSU Haji Surabaya in January-February 2020. The process of collecting data was done through interviews, questionnaires and observation on nursing care. The variables in this research were the level of knowledge, attitude, and behavior of PPE usage. Results: Most of the nurses had poor behavior (50\%) of PPE usage with the majority having a moderate level of knowledge and attitude. Conclusion: There was a positive relation with strong correlation $(\rho=0.635)$ between the level of knowledge and quiet strong correlation $(\rho=0.417)$ between attitude that nurses had with their behavior of PPE usage.
\end{abstract}

Keywords: attitude, behavior of personal protective equipment usage, knowledge, nurses

\section{ABSTRAK}

Pendahuluan: Perawat adalah tenaga kesehatan dengan intensitas interaksi paling tinggi dengan pasien sehingga memiliki risiko tinggi terpajan bahaya di tempat kerja. Kecelakaan kerja dan infeksi nososkomial menjadi salah satu bahaya yang yang mengancam keselamatan dan kesehatan perawat.Penggunaan Alat Pelindung Diri secara tepat menjadi wajib untuk diterapkan sebagai upaya dalam mencegah dan meminimalisasi risiko pajanan atau infeksi. Penelitian ini bertujuan untuk mengidentifikasi perilaku perawat dalam menggunakan Alat Pelindung Diri (APD) serta mengidentifikasi hubungan antara tingkat pengetahuan dan sikap yang dimiliki sebagai faktor internal individu terhadap perilaku perawat dalam menggunakan APD. Metode: Metode penelitian yang digunakan yakni observasional dengan rancangan penelitian cross-sectional. Sampel yang digunakan ditentukan menggunakan total populasi yakni 12 perawat Ruang Rawat Inap Paru RSU Haji Surabaya pada Januari-Februari 2020. Proses pengumpulan data dilakukan melalui kegiatan wawancara, pembagian kuesioner dan kegiatan observasi pada tindakan keperawatan. Variabel dalam penelitian ini antara lain tingkat pengetahuan, sikap, dan perilaku dalam penggunaan APD. Hasil: Sebagian besar perawat memiliki perilaku kurang baik (50\%) dalam penggunaan APD dengan mayoritas memiliki tingkat pengetahuan dan sikap dalam kategori cukup baik. Simpulan: Terdapat hubungan positif dengan tingkat korelasi kuat $(\rho=0,635)$ antara tingkat pengetahuan dan tingkat korelasi cukup kuat $(\rho=0,417)$ antara sikap yang dimiliki perawat dengan perilakunya dalam penggunaan APD.

Kata kunci: pengetahuan, penggunaan alat pelindung diri, perawat, sikap

Corresponding Author:

Gading Diah Zahara Putri

Email: putrigading2512@yahoo.com

Telephone: +6282234075378

\section{INTRODUCTION}

Ministry of Health (2020) has stated that a hospital is a health service industry that provides whole personal health services by providing inpatient, outpatient and emergency facilities. A hospital is a workplace as well as a place for both 
healthy people (workers or visitors) and sick people (patients), so the hospital is one of the complex workplaces with a quite high risk of the emergence of Occupational Diseases or Occupational Accidents and the transmission of various diseases caused by contact with the infectious agents of diseases, blood and body fluids (Anies, 2014).

As an industry engaged in the health sector, hospitals strive to be able to decrease, to the lowest possible, the risk of accidents and diseases emerging from work relationships and to increase productivity and efficiency (Mapanawang, Pandelaki and Panelewen, 2017). Therefore, the role of Hospital Occupational Safety and Health becomes principal to be applied in order to comply with Law of Republic of Indonesia No.36 Year 2009 on Health Article 164, which states that OHS efforts must be carried out in all workplaces especially workplaces that have risks of health hazards to protect workers in order to live healthy and free from occupational health problems. Hospitals fall within such criteria of workplaces.

Potential sources of hazard that can be found in hospitals are caused by biological factors, physical factors, chemical factors, ergonomics factors (methods and positions of work) and psychosocial factors (work shifts and workload), all of which can result in illnesses and work-related accidents for workers, visitors, patients and the people in the surrounding environment (Zahara, Effendi and Khairani, 2017). Of the total number, around $70 \%$ of hazards are fatal, such as death and lifetime disability.

Based on the outcomes of the National Safety Council (NSC) report in 1988, it is stated that work accidents in hospitals proved to be $41 \%$ higher than those occuring in workers in other industries (Mantiri, Pinontoan and Mandey, 2020). Some work accidents that often occur and are found in hospitals include needle sticking or needle stick injury (NSI), sprains, back pain, scratches/cuts, burns, infectious diseases, and others. Dr. Joseph's research in 20052007 noted that the NSI OA rate in Indonesia was $38-73 \%$ of the total health workers (Directorate of Occupational Health Development and Ministry of Health, 2010).

Nurses are the largest percentage of health workers and play an important and big role in the delivery of health services (Ramdan and Rahman, 2018). In Indonesia, nursing services are the largest part of the health workers' duties at hospitals, which are around $47.08 \%$ as nurses interact with patients the most, especially in inpatient services (Suryawati,
2004). Therefore, nurses are health labors in hospitals who have an extreme level of vulnerability and risk of exposure to workplace hazards.

Unfortunately, accidents or infections in health workers are often not recorded properly. Occupational accidents in nurses are considered a serious problem because they threaten the health and well-being of patients and health workers globally (Maria, Wiyono and Candrawati, 2015). This is due to the fact that nurses are health workers who have a big role with a proportion of almost exceeding $50 \%$ of hospital human resources (Rabiatunnisa and Hernike, 2018). Nurses as health workers are an integral part of a medical service, so they are the key to the overall success of quality health services.

Minister of Health Regulation number 27 of 2017 concerning Guidelines for Infection Prevention and Control in Health Care Facilities has stated that nosocomial infection / HAIs (Hospital Acquired Infections) is one of the occupational risks faced by health workers in hospitals. Nosocomial Infections are infections that occur in patients during treatment in hospitals and other health care facilties. These infections are not only limited to patients but also to visitors and health workers who do not carry out nursing procedures correctly, such as PPE usage. In other words, nosocomial infection is one of the occupational risks faced by health workers in hospitals. It is an important condition in the inpatient services in hospitals throughout the world because its incidence is quite high (Nasution, 2012).

To minimize the incidence and severity of occupational accidents and infectious diseases, health workers, in this case nurses, need to apply standard precaution for infection or, generally called, universal precaution. Standard precaution for infection (universal precaution) is one of the efforts of health service centers, in this case hospitals, to protect patients and health workers. Universal Precaution (UP) is a guide made by the Centers for Disease Control and Prevention (CDC) (Puspitasari, 2019).

Based on Centers for Disease Control and Prevention (CDC) in 2011, the main components of universal precaution include hand hygiene, the Personal Protective Equipment (PPE) use, safe injection practices, handling of equipment or surfaces in potentially contaminated patient environments and respiratory hygiene / cough ethics (Satiti, Wigati and Fatmasari, 2017). Ministry of Manpower and Transmigration (2010) has also stated that Personal Protective Equipment is equipment which is able 
to protect a person by isolating either a part or the whole body from hazards in the workplace. The Personal Protective Equipment (PPE) use becomes very important for nurses in carrying out the task of preventing infection when starting nursing care to the patients (Zaki et al., 2018).

The PPE usage by nurses in several hospitals in Indonesia has reached $>40 \%$, but in reality it shows that nurses typically only use one type of PPEs (only a mask, sterile gloves or a lab coat) (Muchlis and Yusuf, 2017). Research of Yulis (2019) on emergency room nurses in type A hospital in Jakarta stated that among 20 respondents, $65 \%$ were in the category of non-compliance. The majority of nurses were still negligent in the use of both clean and sterile gloves.

Behavior refers to all individual activities that can be directly or indirectly observed (Ernawati and Nurlelawati, 2017). The PPE usage is a reflection of nurse's behavior at work that can be observed directly. According to Notoadmodjo (2012), behavior is a combination of internal factors consisting of intelligence, perception, motivation, interests and emotion as well as external factors consisting of group objects and cultural outcomes. Behavior also depends on the characteristics or other factors of the workers themselves (Putri and Denny, 2014). Health workers, in this case nurses, need to have good knowledge and attitude related to the PPE usage in the delivery of health services, considering that PPE has an important function in minimizing transmission (Suharto and Suminar, 2016).

RSU Haji Surabaya is a type B Hospital owned by the Government of East Java Province. It is one of the hospitals that has implemented policies and supervision in the PPE usage. RSU Haji Surabaya has made a policy related to the PPE usage in the form of Standard Operating Procedures (SOP), which has been approved by the Hospital Director since 27 May 2015 until now. The form of supervision of the PPE usage is carried out in regular monthly assessment or supervision of each nurse in each room, but based on the information obtained, the supervision data on the use of PPE has not been processed and followed up; they are still in the form of raw data. RSU Haji Surabaya has also carried out training related to the use of PPE for health workers especially for nurses, both basic and classical training, on a regular basis, but due to the large number of new nurses the training program has not been able to reach the whole.
The pulmonary inpatient ward is a special room located in RSU Haji Surabaya which treats patients with lung diseases such as tuberculosis and others. That inpatient ward is one of the rooms that has a high risk of infection transmission for nurses. Based on the data of Pulmonary Inpatient Ward supervision obtained from the PPI Hospital Committee, it is shown that the level of compliance of PPE usage of nurses has not reached $100 \%$, so it can be concluded that there are discrepancies in the practice of their use. The compliance data for PPE usage in the Pulmonary Inpatient Wards at RSU Haji Surabaya in 2018 showed that obedient nurses were only $52 \%$. The PPE for nurses is basically not used all at once but it is based on the transmission and indication of use. Therefore, a good understanding is needed by each individual. The basic PPE used by nurses includes gloves (sterile and clean), scouts and surgical masks. Based on this background, this research aims to identify the behavior of PPE usage, knowledge and attitude of nurses and also analyze the correlation between the knowledge and attitude towards PPE usage of nurses in the Pulmonary Inpatient Wards at RSU Haji Surabaya.

\section{METHODS}

This study was a quantitative research using analytic observational research design because it was conducted without any treatment, and it aimed to analyze the relationship between variables. The research was conducted at the inpatient (Pulmonary) wards at RSU Haji Surabaya in January-February 2020. The population in this research were all nurses who were assigned on the pulmonary inpatient wards. This research used a total sampling or all populated sampling method, so the number of respondents in the research included all nurses in the pulmonary inpatient wards as many as 12 people.

Data were collected through interviews, questionnaires and observation. The questionnaires were filled in by the respondents to get information related to the characteristics of the respondents as well as the variables to be examined, while observations were made to identify and assess the respondents' behavior in the PPE usage when delivering nursing care to the patients. The data that had been collected were later processed and analyzed.

This research has passed the ethical test and received a certificate with an ethic code 26/EA/ KEPK/2020 from the Health Research Ethics 
Table 1. Coefficient Score and Relation Level

\begin{tabular}{ccl}
\hline & $\begin{array}{c}\text { Correlation } \\
\text { (r) }\end{array}$ & \multicolumn{1}{c}{ Relation Level } \\
& 0.00 & No relation between variables \\
& $>0.00-0.1$ & Very weak relation \\
& $>0.1-0.25$ & Weak relation \\
Relation & $>0.25-0.5$ & Quite strong relation \\
Strength & $>0.5-0.75$ & Strong relation \\
& $>0.75-0.9$ & Very strong relation \\
& $>0.9-1.0$ & Perfect relation \\
\hline Relation & $+($ Positive $)$ & $\begin{array}{l}\text { In the same direction; } \\
\text { the greater the score of xi, the } \\
\text { greater the score of yi and vice } \\
\text { virection }\end{array}$ \\
& $-($ negative $)$ & $\begin{array}{l}\text { In the opposite direction; the } \\
\text { greater the score of xi, the } \\
\text { smaller the score of yi and vice } \\
\text { versa }\end{array}$ \\
\hline & & \\
\hline
\end{tabular}

Committee, Universitas Airlangga Surabaya. Research data were analyzed through univariate and bivariate analysis. Univariate analysis was done to describe the frequency distribution of research variables. Meanwhile, the bivariate analysis used was the correlation test by assessing the correlation coefficient (Spearman rank correlation) to determine the strength and the direction of the relation among the research variables.

The dependent variable in this research was the nurses' behavior of PPE usage in the workplace. Meanwhile, the independent variables examined in this research were the level of knowledge and attitude of nurses related to the PPE usage.

\section{RESULTS}

Overview of Individual Characteristics of Pulmonary Inpatient Wards Nurses at RSU Haji Surabaya

Individual characteristics including age, education level and work period of nurses were obtained through the distribution and filling of questionnaires. Nurse's ages were categorized into 3 categories where the age range was adjusted to the productive age of workers in general. Table 2 shows the results that the majority of nurses $(50 \%)$ assigned in the pulmonary inpatient wards RSU Haji Surabaya Hospital were in the age range of 20-30 years.
Table 2. Distribution of Individual Characteristics Nurses' in the Pulmonary Inpatient Wards at RSU Haji Surabaya in 2020

\begin{tabular}{lcc}
\hline $\begin{array}{l}\text { I n d i v i d u a l } \\
\text { Characteristic }\end{array}$ & Frequency (n) & Percentage (\%) \\
\hline Age & 6 & 50.0 \\
20-30 years & 4 & 33.3 \\
31-40 years & 2 & 16.7 \\
$>40$ year & & \\
\hline Education Level & 10 & 83.3 \\
Diploma & 2 & 16.7 \\
Bachelor & & \\
\hline Working Period & 5 & 41.6 \\
$<5$ years & 2 & 16.7 \\
5-10 years & 5 & 41.6 \\
$>10$ years & & \\
\hline
\end{tabular}

Nurses' education levels were categorized into 2 , namely diploma and bachelor. The categorization was adjusted to the standard of formal education of nurses in general. Table 2 shows the results that the majority of nurses $(83 \%)$ assigned in the pulmonary inpatient wards RSU Haji Surabaya had a diploma degree.

The respondents' working period was counted from the initial entry as a nurse at RSU Haji Surabaya until this research was conducted. Table 2 shows the results that nurses who were assigned in the pulmonary inpatient wards RSU Haji Surabaya with a working period of $<5$ years and $>10$ years had the same ratio $(41.6 \%)$.

\section{Overview of Nurses's Knowledge and Attitude in the Pulmonary Inpatient Wards at RSU Haji Surabaya}

Retrieval of data related to the knowledge and attitudes of respondents regarding the use of PPE was done through filling specific questions on the questionnaires that had been distributed to the respondents. Table 3 shows the results that the majority of nurses $(75.0 \%)$ who were assigned in the pulmonary inpatient wards of RSU Haji Surabaya had a moderate level of knowledge related to the use of PPE, with no nurses having poor level of knowledge. The majority of nurses $(66.7 \%)$ who were assigned in the pulmonary inpatient wards of RSU Haji Surabaya had attitude that tended to be at an moderate level related to the use of PPE. 
Table 3. Distribution of Nurses' Knowledge and Attitude Level in the Pulmonary Inpatient Wards of RSU Haji Surabaya in 2020

\begin{tabular}{ccc}
\hline & Frequency (n) & Percentage (\%) \\
\hline Knowledge Level & & \\
Moderate & 9 & 75.0 \\
Good & 3 & 25.0 \\
\hline Attitude Level & & \\
Moderate & 8 & 66.7 \\
Good & 4 & 33.3 \\
\hline
\end{tabular}

Table 4. Nursing Treatment in the Pulmonary Inpatient Wards at RSU Haji Surabaya in 2020

\begin{tabular}{cl}
\hline No & \multicolumn{1}{c}{ Treatments } \\
\hline 1 & IV line setup and removal \\
2 & Patient's vital sign observation and check-up \\
3 & Oral drugs administration \\
4 & Injection drugs administration (IV, IM, IC, \\
& SC) \\
5 & Oxygen setup \\
6 & Nebulizer (steam administration) \\
7 & NGT setup \\
8 & Blood transfusion \\
9 & Examination of sample collection (blood, \\
10 & spatum, etc.) \\
11 & Patient's urine management \\
12 & Catheter set up and removal and so on \\
\hline
\end{tabular}

Source: Observation results and secondary data at RSU Haji Surabaya, 2020

\section{Overview of Nurses' Behavior of PPE Usage in the Pulmonary Inpatient Wards at RSU Haji Surabaya}

The pulmonary inpatient ward is a specific room that treats patients with pulmonary diseases such as tuberculosis and other pulmonary diseases. Transmission of infection found in the pulmonary inpatient wards are mostly airborne and droplets, but apart from them, transmission could also happen through the patient's body fluids as well as direct contact from the nursing treatment done. The treatments done by the nurses in the pulmonary inpatient wards are shown in Table 4.

PPE for nurses is basically not used all at once but is based on the transmission and indication of use. As health workers who have a high enough interaction with patients in the examination room
Table 5. Observation Results of Nurses' PPE Usage Behavior in the Pulmonary Inpatient Wards at RSU Haji Surabaya in 2020

\begin{tabular}{ccc}
\hline $\begin{array}{c}\text { Behavior of PPE } \\
\text { Usage }\end{array}$ & Frequency (n) & Percentage (\%) \\
\hline Bad & 6 & 50.0 \\
Moderate & 3 & 25.0 \\
Good & 3 & 25.0 \\
\hline Total & 12 & 100 \\
\hline
\end{tabular}

Table 6. Points of assessment of the PPE Usage for Nurses in the Pulmonary Inpatient Wards of RSU Haji Surabaya in 2020

\begin{tabular}{|c|c|}
\hline No & Points of Assessment \\
\hline 1 & Use of closed footwear (covering the instep) \\
\hline 2 & $\begin{array}{l}\text { Use of PPE before making contact with the } \\
\text { patient }\end{array}$ \\
\hline 3 & Procedures for using PPE properly \\
\hline 4 & Wearing PPE according to the indication for use \\
\hline 5 & $\begin{array}{l}\text { Use of PPE for } 1 \text { procedure of nursing care and } \\
1 \text { patient }\end{array}$ \\
\hline 6 & Processing PPE after use (discarded or removed) \\
\hline
\end{tabular}

with a high risk of danger, nurses must implement procedures to prevent or minimize the occurrence of infections and occupational accidents. The use of PPE is a good policy and one of the obligations that must be applied in the workplace. The following is the result of observation on the behavior of PPE usage by nurses in the pulmonary inpatient wards at RSU Haji Surabaya.

Based on the observations of nursing treatment performed by each nurse, it was found that the majority of nurses $(50 \%)$ in the pulmonary inpatient wards of RSU Haji Surabaya had a bad behavior in the use of PPE in the workplace. Observations of PPE Usage in nurse were carried out twice $(2 \mathrm{x})$ on each individual during the nursing care.

The assessment of PPE use in this study was based on 6 points of assessment that support an optimal use of PPE, which are described in Table 6. The assessment points were based on the standard applicable at RSU Haji Surabaya and Regulation of the Minister of Health of Republic of Indonesia Number 27 of 2017 concerning Guidelines for Infection Prevention and Control in Health Care Facilities. The criteria for assessing the behavior of using PPE were divided into 3 categories, which were grouped according to the research location. It was considered good (if it fit with 5-6 assessment 
Table 7. Observation Results of Inconsistencies in the Use of PPE by Nurses in the Pulmonary Inpatient Wards at RSU Haji Surabaya in 2020

\begin{tabular}{cl}
\hline No & \multicolumn{1}{c}{ Behavior } \\
\hline 1 & $\begin{array}{l}\text { Nurses did not use full-covering footwear at work/ } \\
\text { while giving treatment to patients (using flip-flops } \\
\text { and flatshoes) }\end{array}$ \\
2 & $\begin{array}{l}\text { Nurses used the PPE surgical mask during shift } \\
\text { (not replacing it at all) }\end{array}$ \\
3 & $\begin{array}{l}\text { Nurses did not use the PPE sterile gloves when } \\
\text { giving treatment that was potentially exposed to } \\
\text { the patient's body fluids (blood) and chemicals }\end{array}$ \\
4 & $\begin{array}{l}\text { Nurses did not replace the PPE (sterile gloves) } \\
\text { when giving treatment to different patients }\end{array}$ \\
5 & $\begin{array}{l}\text { The use of PPE scout (clothes cover) was not } \\
\text { appropriate, not tied or not buttoned, so it interfered } \\
\text { the treatment process }\end{array}$ \\
\hline
\end{tabular}

Table 8. Relation between Nurses' Knowledge Level and Behavior of PPE Usage in the Pulmonary Inpatient Wards at RSU Haji Surabaya in 2020

\begin{tabular}{cccccccc}
\hline \multirow{2}{*}{$\begin{array}{c}\text { Knowledge } \\
\text { Level }\end{array}$} & \multicolumn{6}{c}{ Behavior of PPE Usage } & \\
\cline { 2 - 6 } & \multicolumn{3}{c}{ Bad } & \multicolumn{3}{c}{ Moderate } & \multicolumn{2}{c}{ Good } & \multirow{2}{*}{ C } \\
\cline { 2 - 6 } & $\mathbf{n}$ & $\mathbf{\%}$ & $\mathbf{n}$ & $\mathbf{\%}$ & $\mathbf{n}$ & $\mathbf{\%}$ & \\
\hline Moderate & 6 & 66.7 & 2 & 22.2 & 1 & 11.1 & \\
Good & 0 & 00.0 & 1 & 33.3 & 2 & 66.7 & 0.635 \\
\hline Total & 6 & 50.0 & 3 & 25.0 & 3 & 25.0 & \\
\hline
\end{tabular}

points), moderate (if it fit with 3-4 assessment points) and bad (if it fit only with 0-2 assessment points). Some violations or discrepancies with the Standard Operating Procedure (SPO) for the use of PPE at RSU Haji Surabaya carried out by nurses during the research process are shown in Table 7.

\section{Relation between Nurses' Knowledge Level and Behavior of PPE Usage in the Pulmonary Inpatient Wards at RSU Haji Surabaya}

Table 8 shows the results that the majority of nurses $(66.7 \%)$ who were assigned in the pulmonary inpatient wards at RSU Haji Surabaya had a moderate level of knowledge with bad behavior in the use of PPE in the workplace. The test conducted shows that a correlation coefficient of 0.635 was obtained, so it can be concluded that the nurses' level of knowledge with behavior PPE usage had a strong relationship with positive direction.
Table 9. Relation between Attitude Level and Behavior of PPE Usage in the Pulmonary Inpatient Wards at RSU Haji Surabaya in 2020

\begin{tabular}{|c|c|c|c|c|c|c|c|}
\hline \multirow{3}{*}{$\begin{array}{c}\text { A t t it u d e } \\
\text { Level }\end{array}$} & \multicolumn{6}{|c|}{ Behavior of PPE Usage } & \multirow{3}{*}{$\mathbf{C}$} \\
\hline & \multicolumn{2}{|c|}{ Bad } & \multicolumn{2}{|c|}{ Moderate } & \multicolumn{2}{|c|}{ Good } & \\
\hline & $\mathbf{n}$ & $\%$ & $\mathbf{n}$ & $\%$ & $\mathbf{n}$ & $\%$ & \\
\hline Moderate & 5 & 62.5 & 2 & 25.0 & 1 & 12.5 & \multirow{3}{*}{0.417} \\
\hline Good & 1 & 25.0 & 1 & 25.0 & 2 & 50.0 & \\
\hline Total & 6 & 50.0 & 3 & 25.0 & 3 & 25.0 & \\
\hline
\end{tabular}

Relation between Nurses' Attitude Level and Behavior of PPE Usage in the Pulmonary Inpatient Wards at RSU Haji Surabaya

Table 9 shows the results that the majority of nurses $(62.5 \%)$ who were assigned in the pulmonary inpatient wards at RSU Haji Surabaya had a moderate attitude with bad behavior in the use of PPE in the workplace. The test conducted shows that a correlation coefficient of 0.417 was obtained, so it can be concluded that the relation between nurses' attitude level with their behavior in using PPE had a fairly strong level of correlation with a positive direction.

\section{DISCUSSION}

\section{Relation between Nurses' Knowledge Level with Behavior of PPE Usage}

In this research, the knowledge in question was the nurses' understanding on the forms of danger, the types of PPE and ways to use the PPEs properly in accordance with urgency. The knowledge is the result of knowing what happens over sensing processes, specifically the sense of sight and hearing of specific things. Knowledge can be said as a very important domain in the formation of behavior. Knowledge can be the foundation of a person's behavior to be more durable (Notoatmodjo, 2012).

This research shows that the nurses' knowledge level was strongly correlated $(\mathrm{C}=0.635)$ with behavior of PPE usage. The results show that nurses with a good knowledge level would tend to have good behavior of PPE usage in each nursing procedure performed. In line with the concept of behavior in the Lawrence Green Theory which states that knowledge is one form of predisposing factor which is an internal factor that can facilitate someone in taking action or behaving (Notoadmodjo, 2012). 
Individual knowledge is strongly related to one's behavior because knowledge is a major factor for decision making for a spesific purpose. In other words, knowledge can be the basis for someone to act right without causing danger to one's self (Ardenny, 2015). In line with the research by Herawati, Agusni and Ifitri (2018) focusingon dental nurses, teh result suggests there is a strong relationship among nurses' knowledge about the risks of danger (infectious diseases) to nurses' behavior of PPE usage. Nurses who have a good understanding of the dangers of their work will tend to be better in following the SOP of PPE usage.

The results show the majority of nurses in the pulmonary inpatient wards at RSU Haji Surabaya was in the moderate category with no one having poor knowledge. This could be due to the high educational background of nurses (diploma and bachelor) as workers who are required to have qualifications and specific expertise. In fact, level of education has a close relation with knowledge level of a person. A higher level of education will help increase and enhance insight for individuals (Dalimunthe and Mithami, 2018).

Observed deeply, formal education is not the only increasing factor of insight or knowledge. In fact, nurses' knowledge can be obtained through both formal and non-formal education (training, experience), both of which provide a short-term effect on the change or improvement of individual's knowledge (Sari and Wiryansyah, 2019). Training has a close relation with education in order to improve individual's skills. Besides, training is also a process of someone getting new knowledge or information (Wicaksono, 2017). Likewise, experience can be used as a source of insight and knowledge through efforts to repeat things that have happened, and to solveproblems faced in the past (Gumelar and Ardyanto, 2018).

Nurses as health care providers who deal directly with patients are required to have the ability and understanding on how to prevent transmission of infections in hospitals. This is the key of providing quality services (Puspitasari, 2019). In this case, the use of PPE is a form of transmission prevention in hospitals that acts as a physical barrier to infection of blood or other bodily fluids. A proper PPE usage must be adapted to the transmission and urgency of the performed treatment. Therefore, the nurses' knowledge becomes important and is highly related to help understand the role, types, and use of PPE that is appropriate and effective to protect the nurses themselves, patients, and health facilities from the spread of pathogens that are infectious (Brown, Munro and Rogers, 2019).

\section{Relation between Attitude with Behavior of PPE Usage}

The attitude referred in this study is the response or perception of nurses to the PPE usage in workplace. Attitude is a readiness to act and not an implementation of certain motives. Attitude cannot be called an action but can be said to be a predisposition of a behavior to be carried out (Notoadmodjo, 2010).

This research shows the nurses' attitude was strongly correlated $(C=0.417)$ with their behavior in PPE usage. This is in line with the research of Zaki et al. (2018), which stated that there was a relation between attitudes towards the behavior of nurses in PPE usage. The majority of nurses in the pulmonary inpatient wards at RSU Haji Surabaya with moderate attitude had poor behavior and the majority of nurses with good attitude had good behavior. Thus, it can be concluded that the better the attitudes of nurses towards PPE usage, the better the behavior in the use of PPE for each nursing treatment procedure performed.

A worker who has a better attitude will have the possibility to use PPE during work seven times greater than a worker who has less attitude (Farsida and Zulyanda, 2019). Ajzen and Fishein (1980) reinforce the results of this research with TRA Theory (Theory Reasoned of Action) which states that behavior is influenced by attitudes through a decision making process in detailed or thorough consideration, and it is also full of reasons yet have limited impacts (Gunawan and Mudayana, 2016). A person's behavior is basically based on a stage that is knowledge-attitudes-behavior. Based on that stage, there is a visible relation between a person's attitude and behavior as an individual with knowledge and understanding will determine their attitude towards an object, which will later be realized in the form of an action or behavior (Winarti, 2018).

Based on its distribution, the majority of nurses $(66.7 \%)$ had moderate attitudes with none of them having poor attitudes. In relation to this, individual attitudes can be influenced by physical and mental assistance. One form of mental assistance is in the form of orders, rules and direction which will be considered as a form of support (Wulandini and Roza, 2017). The formation of attitudes and behavior of nurses in the pulmonary inpatient 
wards at RSU Haji Surabaya can be built upon the enactment of written policies related to K3RS (Hospital Occupational Safety and Health) at RSU Haji Surabaya, especially in terms of PPE usage for health workers. Apart from policy, there is also an Infection Prevention and Control Link Nurse (IPCLN) in every room at RSU Haji Surabaya, one of which is to supervise, control and provide direction for PPE usage for health workers.

A positive attitude in oneself is formed or determined by the surrounding environment, one of which is influenced by knowledge and information obtained from an object (Harlan, 2017). Nurses with sufficient knowledge will then know the danger and benefits in using PPE that have an impact on the positive attitude, which will emerge towards the attitude object. The object of attitude referred to in this research is Personal Protective Equipment.

The tendency of positive attitudes possessed by nurses in the pulmonary inpatient wards at RSU Haji Surabaya could occur as a form of responsibility reflected by nurses as health workers who are the main determinants of quality health services. Furthermore, positive individual attitudes towards an object can be caused by anxiety and fear of a thing (Liswanti, 2017). A nurse who is afraid and worried about the safety of herself and the patient will do the job safely in accordance with the established procedures.

\section{CONCLUSION}

The majority of nurses in the pulmonary inpatient wards at RSU Haji Surabaya based on behavior of PPE usage assesment were mostly $(50 \%)$ in the bad category with a moderate level of knowledge and attitude in PPE usage. Based on the research conducted, there was a positive relation between nurses' knowledge and attitude towards behavior of PPE usage with a strong and moderate correlation level.

As one of the factors related to nurse behavior, some efforts must be made to increase and maintain knowledge and attitudes to improve the behaviour of PPE usage. The implementation of regular training and socialization to nurses on a regular basis and even distributionthrough structured scheduling can help to improve, maintain, and refresh nurses' knowledge. RSU Haji Surabaya can also carry out routine monthly evaluation activities based on the raw data supervision of the use of APD and do a safety briefing on the use of PPE before work, which can be carried out in front of all nurses in each room when they are changing shifts. These efforts can help to improve and maintain the attitude of nurses to always remember to use PPE properly.

\section{ACKNOWLEDGEMENTS}

The author would like to say thank you to everyone who has helped carry out this research. Special thanks is particularly given to RSU Haji Surabaya as a place of research from the Education and Training Department, the Head of Inpatient Wards who has assisted the licensing so that the research could take place to the nurses for taking the time to become the respondents in this research. Also, gratitude is given to the supervisor who has provided guidance and the Faculty of Public Health, Airlangga University as a place to gain knowledge deeper.

\section{REFERENCES}

Anies (2014) Kedokteran Okupasi. Yogyakarta: Ruzz Media.

Ardenny (2015) 'Faktor Yang Berhubungan Dengan Kecelakaan Kerja Pada Perawat Di Rumah Sakit Jiwa Tampan Pekanbaru Tahun 2015', Jurnal Proteksi Kesehatan, 4(1), pp. 1-6.

Brown, L., Munro, J. and Rogers, S. (2019) 'Use of Personal Protective Equipment in Nursing Practice', Nursing Standard (Royal College of Nursing (Great Britain), 34(5), pp. 59-66.

Dalimunthe, K. T. and Mithami, D. B. (2018) 'Hubungan Pengetahuan, Sikap, Dan Tindakan Terhadap Pemakaian Alat Pelindung Diri (Apd) Pada Pekerja Las Besi Di Kecamatan Percut Sei Tuan Kabupaten Deli Serdang Tahun 2018', Jurnal Stikna, 02(October), pp. 1-6.

Directorate of Occupational Health Development and Ministry of Health (2010) 'Keputusan Menteri Kesehatan RI Nomor 1087/Menkes/SK/VIII/2010 tentang Standar Kesehatan dan Keselamatan Kerja Di Rumah Sakit'. Jakarta: Kementerian Kesehatan Republik Indonesia Direktorat Bina Kesehatan Kerja.

Ernawati, N. and Nurlelawati, E. (2017) 'FaktorFaktor Yang Berhubungan Dengan Pelaksanaan Penerapan K3 Di RSIA Permata Sarana Husada Periode Februari 2015', Jurnal Akademi Keperawatan Husada Karya Jaya, 3(1), pp. 12-18. 
Farsida, F. and Zulyanda, M. (2019) 'Analisis Penggunaan Alat Pelindung Diri Dalam Penanganan Sampah Medis Pada Petugas Cleaning Service Di RSUD Kabupaten Bekasi Tahun 2016', Jurnal Kesehatan, 12(1), pp. 14-23.

Gumelar, F. and Ardyanto, D. (2018) 'Hubungan Kepatuhan Dan Pengetahuan Tentang APD Dengan Safety Talk Di Unit Maintenance Perusahaan Semen', Journal of Public Health Research and Community Health Development, 1(2), pp. 155-165.

Gunawan, I. and Mudayana, A. A. (2016) 'Hubungan Antara Pengetahuan, Sikap Dan Motivasi Dengan Perilaku Penggunaan Alat Pelindung Diri Pada Pekerja Bagian Produksi PT. Katingan Indah Utama, Kabupaten Kotawaringin Timur, Provinsi Kalimantan Tengah', Unnes Journal of Public Health, 5(4), pp. 336-347.

Harlan, A. N. (2017) 'Faktor Yang Berhubungan Dengan Perilaku Penggunaan APD Pada Petugas Laboratorium Rumah Sakit PHC Surabaya', The Indonesian Journal of Occupational Safety and Health, 6(3), pp. 278-287.

Herawati, N., Agusni, F. and Ifitri, I. (2018) 'Penggunaan APD Di Poliklinik Gigi Berdasarkan Tingkat Pengetahuan Perawat Gigi Tentang Penyakit Menular', Jurnal Kesehatan Masyarakat Andalas, 12(1), pp. 32-38.

Liswanti, Y. (2017) 'Hubungan Tingkat Pengetahuan Dan Sikap Dengan Perilaku Penggunaan Alat Pelindung Diri Pada Mahasiswa Prodi III Analis Kesehatan Stikes BTH Tasikmalaya', Jurnal Kesehatan Bakti Tunas Husada, 17(2), pp. 502-512.

Mantiri, Pinontoan, O. and Mandey, S. (2020) 'Faktor Psikologi Dan Perilaku Dengan Penerapan Manajemen Keselamatan Dan Kesehatan Kerja Rumah Sakit', Indonesian Journal of Public Health and Community Medicine, 1(3), pp. 19-27.

Mapanawang, S., Pandelaki, K. and Panelewen, J. (2017) 'Hubungan Antara Pengetahuan, Kompetensi, Lama Kerja, Beban Kerja Dengan Kejadian Tertusuk Jarum Suntik Pada Perawat Di RSUD Liun Kendage Tahuna', Jurnal EMBA, 5(3), pp. 4336-4345.

Maria, S., Wiyono, J. and Candrawati, E. (2015) 'Kejadian Kecelakaan Kerja Perawat Berdasarkan Tindakan Tidak Aman', Jurnal Care, 3(2), pp. 9-17.
Ministry of Health (2020) 'Peraturan Menteri Kesehatan Nomor 30 Tahun 2020 Tentang Klasifikasi Dan Perizinan Rumah Sakit'. Jakarta: Kementerian Kesehatan Republik Indonesia.

Ministry of Manpower and Transmigration (2010) 'Peraturan Menteri Tenaga Kerja dan Transmigrasi Republik Indonesia Nomor PER.08/ MEN/VII/2010 tentang Alat Pelindung Diri (APD)'. Jakarta: Kementerian Tenaga Kerja Dan Transmigrasi RI.

Muchlis, S. and Yusuf, M. (2017) 'Kesadaran Perawat Dalam Penggunaan ALat Pelindung Diri (APD)', Jurnal Ilmiah Mahasiswa Fakultas Keperawatan, 2(3), pp. 1-8.

Nasution, L. H. (2012) 'Infeksi Nosokomial', MDVI,39(17), pp. 36-41.

Notoadmodjo, S. (2010) Ilmu Perilaku Kesehatan. Jakarta: Rineka Cipta.

Notoadmodjo, S. (2012) Promosi Kesehatan Dan Perilaku Kesehatan. Jakarta: Rineka Cipta.

Puspitasari (2019) 'Determinants Kepatuhan Dalam Penerapan Universal Precaution', Indonesian Journal of Occupational Safety, Health and Environment, 8(1), pp. 94-103.

Putri, K. and Denny, Y. (2014) 'Analisis Faktor Yang Berhubungan Dengan Kepatuhan Menggunakan Alat Pelindung Diri', The Indonesian Journal of Occupational Safety, Health and Environment, 1(1), pp. 24-36.

Rabiatunnisa and Hernike, L. (2018) 'Hubungan Faktor Individu, Organisasi, Psikologi Dengan Kinerja Perawat di Rumah Sakit Sinar Husni Medan', Jurnal Rekam Medic, 1(2), p. 95-105.

Ramdan, I. M. and Rahman, A. (2018) 'Analisis Risiko Kesehatan dan Keselamatan Kerja (K3) pada Perawat', Jurnal Keperawatan Padjadjaran, 5(3), pp. 229-241.

Sari, L. and Wiryansyah, O. A. (2019) 'Perawatan Luka', Jurnal Kesehatan dan Pembangunan, 10(19), pp. 44-55.

Satiti, A., Wigati, P. and Fatmasari, E. (2017) 'Analisis Penerapan Standard Precautions Dalam Pencegahan Dan Pengendalian Hais (Healthcare Associated Infections) Di RSUD Raa Soewondo Pati', Jurnal Kesehatan Masyarakat Universitas Diponegoro, 5(1), pp. 40-49.

Suharto, S. and Suminar, R. (2016) 'Hubungan Pengetahuan Dan Sikap Perawat Dengan Tindakan Pencegahan Infeksi Di Ruang Icu Rumah Sakit', Jurnal Riset Hesti Medan Akper Kesdam I/BB Medan, 1(1), pp. 1-9. 
Suryawati, C. (2004) 'Kepuasan Pasien Rumah Sakit (Tinjauan Teoritis Dan Penerapannya Pada Penelitian)', JMPK, 07(04), pp. 189-194.

Wicaksono, D. T. (2017) 'Penyebab Terjadinya Substandard Practice Berdasarkan Teori Loss Causation Model Pada Pengelas Di PT Bangun Sarana Baja', The Indonesian Journal of Occupational Safety and Health, 6(3), pp. 299-311.

Winarti, R. (2018) 'Hubungan Pengetahuan Sikap Motivasi Dengan Praktek Perawat Dalam Penggunaan Alat Pelindung Diri Di RSUD Soewondo Kendal', Jurnal Ilmu dan Teknologi Kesehatan, 9, pp. 96-111.

Wulandini, P. and Roza, A. (2017) 'Perilaku Perawat Dalam Penggunaan Alat Pelindung Diri (APD) Di IRNA Medikal RSUD Pekanbaru 2016', Jurnal Keperawatan Abdulrabb, 1(1), pp. 1-9.
Yulis, R. (2019) 'Kepatuhan perawat memakai APD sarung tangan', Jurnal Mitrasehat, IX(2), pp. 513-522.

Zahara, R. A., Effendi, S. U. and Khairani, N. (2017) 'Kepatuhan Menggunakan Alat Pelindung Diri ( APD ) Ditinjau dari Pengetahuan dan Perilaku pada Petugas Instalasi Pemeliharaan Sarana Dan Prasarana Rumah Sakit (IPSRS )',Jurnal Ilmu Kesehatan, 2(2), pp. 153-158.

Zaki, M. et al. (2018) 'Faktor-Faktor Yang Mempengaruhi penggunaan Alat Pelindung Diri (APD) Tenaga Kesehatan Perawat Di RSUD Dr. RM. Pratomo Bagansiapiapi Kabupaten Rokan Hilir', Excellent Midwifery Journal ,1(2), pp. 85-92. 